\title{
FAKTOR-FAKTOR YANG BERHUBUNGAN DENGAN KEJADIAN ATHRITIS RHEUMATOID PADA LANSIA DI WILAYAH KERJA PUSKESMAS MUARA KATI KABUPATEN MUSI RAWAS
}

\author{
Nadi Aprilyadi ${ }^{1}$,Bambang Soewito ${ }^{2}$ \\ Politeknik Kesehatan Palembang \\ Email : aprilyadi@gmail.com
}

\begin{abstract}
ABSTRAK
Arthritis Rheumatoid paling banyak ditemui dan biasanya dari faktor, genetik, jenis kelamin, infeksi, berat badan/obesitas, usia, selain ini faktor lain yang mempengaruhi terhadap penyakit Arthritis Rheumatoid adalah tingkat pengetahuan penyakit sendiri memang masih sangat kurang, baik pada masyarakat awam maupun kalangan medis (Mansjoer, 2011).Tujuan penelitian iniuntukmengetahui faktor-faktor yang berhubungan dengan kejadian Arthritis Rheumatoid pada lansia diwilayah kerja Puskesmas MuaraKati tahun 2018. Penelitian ini menggunakan metode Survey Analitik dengan pendekatan Cross Sectional.

Adapun responden ini adalah Pengambilan sampel dilakukan secara Accidental Sampling yaitu semua lansia yang berkunjung ke poliklinik Puskesmas Muara Kati tahun 2018 yang berjumlah 339 orang dengan mengambil kasus atau responden yang kebetulan ada atau terjadi. Sebagian besar responden berjenis kelamin terhadap kejadian AthritisRheumatoid pada lansia diperoleh hasil tertinggi yaitu kategori laki-laki berjumlah 54 (63.5\%) orang. Sebagian besar Usia lansia yang mempunyai penyakit Athritis Rheumatoid pada lansia diperoleh hasil tertinggi yaitu usia pertengahan berjumlah 47 (55.3\%) responden. Dari responden pengetahuan terhadap kejadian Athritis Rheumatoid pada lansia diperoleh hasil tertinggi yaitu kategori baik berjumlah 36 (42.4\%) orang. Kejadian Athritis Rheumatoid pada lansia di wilayah kerja Puskesmas Muara Kati di peroleh hasil tertinggi yaitu responden yang menderita Athritis Rheumatoid sebanyak 51 (60.0\%). Tidak ada hubungan yang bermakna antara jenis kelamin terhadap kejadian Athritis Rheumatoid pada lansia diwilayah kerja Puskesmas Muara Kati Tahun 2018.

Hasil penelitian ini dapat di jadikan untuk mengembangkan pendidikan tentang cara mendeteksi gejala dari penyakit rematik pada lansia dapat di jadikan bahan pertimbangan dalam pemberian penyuluhan kesehatan pada lansia, terutama penyuluhan tentang penyakit yang menyerang usia lanjut.
\end{abstract}

Kata Kunci : Usia, Jenis Kelamin, Pengetahuan, Arthritis Rheumatoid, Lansia

\section{ABSTRACT}

Rheumatoid arthritis or achy rheumatic pain is also a degenerative disease that causes damage to cartilage (cartilage) of the joints and adjacent bones, accompanied by proliferation of bone and soft tissue in and around the affected area (Priyanto, 2009). The purpose of this study was to determine the factors associated with the incidence of Rheumatoid Arthritis in the elderly in the work area of Muara Kati Health Center in 2018. This study used an Analytical Survey method with a Cross Sectional approach. The respondents were all elderly who visited the Muara Kati Puskesmas clinic in 2018, totaling 339 people. Most of the respondents who were sex with the incidence of Rheumatoid Athritis in 
the elderly obtained the highest results, namely the male category totaling 54 (63.5\%) people. Most of the age of the incidence of Rheumatoid Athritis in the elderly obtained the highest results, namely middle age, amounting to 47 (55.3\%) respondents. Nearly the majority of respondents knowledge of the incidence of Rheumatoid Athritis in the elderly obtained the highest results in the good category totaling $36(42.4 \%)$ people. Most of the incidence of Rheumatoid Athritis in the elderly in the working area of the Muara Kati Health Center was obtained the highest results, respondents who suffered from Rheumatoid Athritis were 51 (60.0\%). There is no significant relationship between sex with the incidence of Rheumatoid Athritis in the elderly in the work area of Muara Kati Health Center in 2018. There is a significant relationship between age and the incidence of Rheumatoid Athritis in the work area of Muara Kati Health Center in 2018. There is a significant relationship between knowledge of events Rheumatoid Athritis in the working area of the Muara Kati Health Center in 2018.

\section{PENDAHULUAN}

Arthritis Rheumatoid adalah penyakit inflamasi sistemik kronis, inflamasi sistemik yang dapat mempengaruhi banyak jaringan dan organ, tetapi terutama menyerang fleksibel (sinovial) sendi. Arthritis Rheumatoid adalah suatu penyakit yang menyerang sendi, dan dapat menyerang siapa saja yang rentan sterkena penyakit Arthritis Rheumatoid(Sarwono, 2011) . Oleh karena itu, perlu kiranya mendapatkan perhatian yang serius karena penyakit ini merupakan penyakit persendian sehingga akan mengganggu aktivitas seseorang dalam kehidupan seharihari.

Penderita Arthritis Rheumatoid di seluruh dunia telah mencapai angka 355 juta jiwa, artinya 1 dari6 orang di dunia ini menderita Artritis Rheumatoid. Diperkirakan angka terus bertambah hingga tahun 2025 dengan indikasi lebih dari $25 \%$ akan mengalami kelumpuhan. Munculnya penyakit ini memang pada usia lanjut. Namun secara komulatif,jumlah penderita yang besar adalah kelompok usia lanjut dan jumlahpaling kecil pada balita.WHO melaporkan bahwa $20 \%$ penduduk dunia terserang Artritis Rheumatoid dimana 5-10\% adalah yang berusia diatas 60 tahun (Taja, 2011).Jumlah penderita Arthritis Rheumatoid di Indonesia pada tahun 2011 diperkirakankan prevalensinya mencapai $29,35 \%$, pada tahun 2012 prevalensinya sebanyak 39,47\%, dan tahun 2013 prevalensinya sebanyak45,59\% dan pada tahun 2014 prevalensiArthritis Rheumatoid di SulawesiUtara sebanyak 24,7\% (Kemenkes, 2012).
Arthritis Rheumatoid paling banyak ditemui dan biasanya dari faktor, genetik, jenis kelamin, infeksi, berat badan/obesitas, usia, selain ini faktor lain yang mempengaruhi terhadap penyakit Arthritis Rheumatoid adalah tingkat pengetahuan penyakit sendiri memang masih sangat kurang, baik pada masyarakat awam maupun kalangan medis (Mansjoer, 2011).

Penyakit peradangan sendi biasanya dirasakan terutama pada sendi- sendi bagian jari dan pergelangan tangan, lutut dan kaki, dan pada stadium lanjut penderita tidak dapat melakukan aktivitas sehari-hari dan kualitas hidupnya akan menurun (Sarwono, 2011).

Pola makan yang salah menjadi salah satu pencetus terjadinya kekambuhan Arthritis Rheumatoid seperti, produk kacang-kacangan seperti susu kacang, kacang buncis, organ dalam hewan seperti; usus, hati, limpa, paru, otak, dan jantung, makanan kaleng seperti, sarden, kornet sapi, makanan yang dimasak menggunakan santan kelapa, beberapa jenis buah-buahan seperti durian dan produk olahan melinjo, minuman seperti alkohol dan sayur seperti kangkung dan bayam (Putri, 2012).

Penyakit Arthritis Rheumatoid ini tidak mengenal batas usia, dari anak-anak sampai usia lanjut. Hanya saja golongan yang lebih banyak menderita Artritis Rheumatoid ini terutama orang dewasa muda sampai pertengahan (usia kerja). Penyakit ini juga tidak mengenal jeniskelamin (Handriani, 2011).

Rematik atau Arthritis Rheumatoid mengakibatkan peradangan pada lapisan dalam 
pembungkus sendi. Penyakit ini berlangsung tahunan, menyerang berbagai sendi biasanya simetris, jika radang ini menahun, terjadi kerusakan pada tulang rawan sendi, tulang otot ligament dalam sendi (Handriani, 2011).

\section{Metodologi Penelitian}

\section{A. Tempat dan Waktu Penelitian}

Penelitian ini dilaksanakan pada bulan Juni - Desember 2018. Tempat penelitian adalah di Wilayah Kerja Puskesmas Muara Kati Kabupaten Musi Rawas.

\section{B. Metode Penelitian}

\section{Desain Penelitian}

Penelitian ini merupakan Jenis penelitian yang digunakan adalah metode Survey Analitik dengan pendekatan Cross Sectional yaitu metode penelitian yang dilakukan dengan tujuan utama yaitu untuk mendapatkan gambaran atau deskripsi tentang suatu keadaan secara objektif (Notoatmodjo, 2005) dan rancangancross sectional berarti pengukuran variabel dependen maupun independen dilaksanakan satu kali pada suatu saat (Nursalam, 2003; Arikunto, 2006).

\section{Populasi dan Sampel Penelitian \\ a.Populasi Penelitian}

Populasi merupakan keseluruhan subjek penelitian (Notoadmodjo, 2002; Arikunto, 2006). Yang menjadi populasi dalam penelitian ini adalah semua lansia yang berkunjung ke poliklinik Puskesmas Muara Kati tahun 2017 yang berjumlah 339 0rang.

\section{b.Sampel Penelitian}

Pengambilan sampel dilakukan secara Accidental Sampling Jadi jumlah sampel adalah 85 responden lansia yang berkunjung ke poliklinik Pukesmas MuaraKati

Kriteria Inklusi pada penelitian ini adalah :

1. Pasien yang dating ke Poliklinik Puskesmas Muara Kati

2. Dalam kondisi sehat secara fisik dan mental
3. bersedia dengan menanda tangani inform Consent

Kriteria Inklusi pada penelitian ini adalah :
1. Memiliki
penyakit
Arthritis Rheumatoid

Sampel penelitian ini berjumlah 85 orang yang semua nya bersedia menjadi responden dan menandatangi informed concent

2. Jenis, cara dan Alat Penelitian

\section{a. Pengumpulan Data}

Penelitian ini menggunakan data primer yang dikumpulkan dengan instrument berupa kuesioner yang berisi pertanyaan yang memiliki beberapa alternatif jawaban. Peneliti melakukan sendiri pengumpulan data dari penduduk di Puskesmas Muara Kati. Pada kuesioner juga disertakan beberapa pertanyaan yang berfungsi untuk mndapatkan data karakteristik pasien dan beberapa faktor lain yang berhubungan dengan pasien yaitu umur, pendidikan. Hal ini untuk mengidentifikasi adanya pengaruh faktor-faktor lain yang diperkirakan berhubungan dengan luaran penelitian.

\section{a. Variabel Dependen}

1. Arthritis Rheumatoid

a. Definisi gangguan berupa

kekakuan, pembengkakan, nyeri dan kemerahan pada daerah persendian dan jaringan sekitarnya (Adellia, 2011)

\section{b. Alat Quesioner} ukur

c. Cara Wawancara Ukur

d. Hasil 1. Ya Ukur 2. Tidak

e. Skala Ordinal Ukur 
b. Variabel Independen

1. Jenis Kelamin

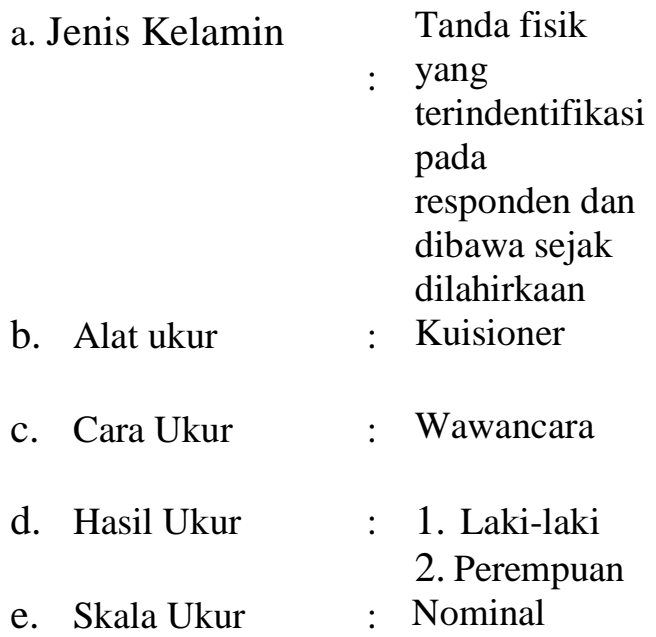

2. Usia
a. Definisi
Umur yang ada pada
b. Alat Kuisioner
ukur
c. Cara Wawancara
Ukur
d. Hasil
1. $>60$ tahun
Ukur
2. $<60$ tahun
e. Skala
Ordinal
Ukur

3. Pengetahuan
a. Definisi Tingakt pengetahuan yang dimiliki oleh manusia terhadap suatu ilmu
b. Alat Kuisioner
ukur
Wawancara
c. Cara
d. Hasil
1. Baik
Ukur
2. Kurang
e. Skala
Ordinal
Ukur

a. Skala Ukur Ordinal

\section{Pengolahan dan Analisa Data}

Proses pengolahan data dalam penelitian ini menggunakan perangkat lunak pengolahan statistik komputer dengan tahapansebagai berikut :

\section{Analisis Univariat}

Analisis univariat digunakan untuk menjabarkan secara deskriptif untuk mengetahui distribusi frekuensi dan proporsi masing-masing variabel yang diteliti, baik variabel independen maupun variabel dependen, kemudian hasil analisis univariat ini di sajikan dalam bentuk tabel dan di deskripsikan makna data yang didapat.

\section{Analisis Bivariat}

Analisis ini digunakan untuk menguji hipotesis dengan menentukan hubungan variabel independen dan variabel dependen melalui Uji Statistik Chi-Square karena data yang dianalisis merupakan data kategorik dengan kategorik.

Proses pengujian Chi - Square menggunakan software komputer untuk pengolahan data statistik. Untuk melihat kemaknaan perhitungan statistik antara variabel dependen dan variabel independen digunakan tingkat kepercayaan $95 \%$.

1) Jika nilai $p$ yang didapat lebih kecil dari 0,05 berarti antara dua variabel (independen dan dependen) yang diteliti mempunyai hubungan yang bermakna.

2) Jika nilai $p$ value lebih besar dari 0,05 maka berarti bahwa antara dua variabel (independen dan dependen) yang diteliti tidak mempunyai hubungan yang bermakna.

Dilakukan 7 kali analisis bivariat yaitu sesuai dengan jumlah variable independen. Kemudian hasil $p$ value yang didapat di bandingkan dengan nilai $\alpha=0,05$ untuk mengetahui ada tidaknya hubungan antar variable dependen dan masing-masing independen. Dan dari penelitian yang dilakukan Adahubungan yangbermaknaantarausia terhadap kejadian Athritis Rheumatoid di wilayah kerja Puskesmas Muara Kati Tahun 2018. Ada hubungan yang bermakna antara pengetahuan terhadap kejadian Athritis Rheumatoid di wilayah kerja Puskesmas Muara Kati Tahun 2018. 


\section{Hasil Dan Pembahasan}

\section{A. Gambaran Umum}

Puskesmas Muara Kati Kecamatan Tiang Pumpung Kepungut merupakan Salah satu dari 27 Puskesmas yang ada di Kabupaten Musi Rawas. Puskesmas Muara Kati di Bangun Tahun 2009 dengan Luas Wilayah 32.646,69Ha. Dengan Jumlah Penduduk 14540 jiwa. Puskesmas Muara kati terletak di Jln. Lintas Sumatera Desa Muara Kati Baru I Kecamatan Tiang Pumpung Kepungut Kabupaten Musi Rawas. Jarak dari Ibukota Kabupaten $\pm 25 \mathrm{KM}$ dapat ditempuh \pm 30 menit dengan kendaraan bermotor. Puskesmas Muara Kati dalam memberikan Pelayanan Kesehatan hanya bersifat Poli Umum/ berobat Jalan dan ada juga pelayanan UGD (UnitGawat Darurat) selamajam kerja.

\section{Hasil Analisis Univariat}

Berdasarkan penelitian yang telah dilakukan, didapatkan sampel sebanyak 85 responden dan hasil penelitian akan disajikan secara deskriptif dalam bentuk tabel dan grafik sebagai berikut

\section{Jenis Kelamin}

\section{Tabel 4.7}

Distribusi Frekuensi Jenis Kelamin Responden denganKejadian Arthritis Rheumatoid pada Lansia di WilayahKerjaPuskesmas MuaraKati Tahun 2018

\begin{tabular}{ccc}
\hline Kategori & Frekuensi & Persentase (\%) \\
\hline Laki-laki & 54 & 63,5 \\
Perempuan & 31 & 36,5 \\
\hline Total & $\mathbf{8 5}$ & 100,0 \\
\hline
\end{tabular}

Berdasarkan Tabel4.7 bahwa sebagian besar pemderita Athritis Reumathoid berjenis kelamin Laki-laki
2. Usia

Tabel 4.8

Distribusi Frekuensi Usia dengan Kejadian Arthritis Rheumatoid pada Lansia di Wilayah Kerja Puskesmas Muara Kati Tahun 2018

\begin{tabular}{ccc}
\hline Kategori & Frekuensi & Persentase (\%) \\
\hline usia pertengahan & 65 & 76,5 \\
usia lanjut & 20 & 23,5 \\
\hline Total & $\mathbf{8 5}$ & 100,0 \\
\hline
\end{tabular}

Berdasarkan Tabel 4.8 bahwa sebagian besar responden paling banyak usia pertengahan.

\section{Pengetahuan}

Tabel 4.9

Distribusi Frekuensi Pengetahuan Responden dengan Kejadian Arthritis Rheumatoid pada Lansia di Wilayah Kerja Puskesmas Muara KatiTahun 2018

\begin{tabular}{ccc}
\hline Kategori & Frekuensi & Persentase (\%) \\
\hline Baik & 38 & 44,7 \\
Cukup & 17 & 20,0 \\
Kurang & 30 & 35,3 \\
\hline Total & $\mathbf{8 5}$ & 100,0 \\
\hline
\end{tabular}

Berdasarkan tabel4.9 bahwa sebagian besar responden berpengetahuan baik

\section{Hasil Analisis Bivariat}

1. Hubungan Jenis Kelamin Responden dengan Kejadian Arthritis Rheumatoid pada Lansia

Tabel 4.10

Hubungan Jenis Kelamin Responden dengan Kejadian Arthritis Rheumatoid pada Lansia di Wilayah Kerja Puskesmas Muara Kati Tahun 2018

\begin{tabular}{cccccccc}
\hline & \multicolumn{4}{c}{ Arthritis Rheumatoid } & \multicolumn{2}{c}{ Total } & \multirow{2}{*}{$\rho$} \\
\cline { 2 - 6 } Jenis Kelamin & \multicolumn{3}{c}{ Ya } & \multicolumn{2}{c}{ Tidak } & \multicolumn{2}{c}{$\%$} \\
\cline { 2 - 6 } & $\mathrm{n}$ & $\%$ & $\mathrm{n}$ & $\%$ & $\mathrm{n}$ & $\%$ & \\
\hline Laki-laki & 37 & 68.5 & 17 & 31.5 & 54 & 100 & \\
Perempuan & 14 & 45.2 & 17 & 54.8 & 31 & 100 & \multirow{2}{*}{0.059} \\
\hline Jumlah & 51 & 60.0 & 34 & 40.0 & 85 & 100 & \\
\hline
\end{tabular}

Dari 54 responden yang berjenis kelamin lakilaki ada 37 (68.5\%) yang menderita Arthritis Rheumatoid. Dari 31 responden yang berjenis 
kelamin perempuan ada 17 (54.8\%) orang tidak menderita Arthritis Rheumatoid.

Hasil analisis Chi Square di dapat $p=$ $0.059(p<\alpha 0.05)$ dengan demikian tidak ada hubungan antara jenis kelamin responden dengan kejadian Arthritis Rheumatoid Pada Lansia. Dari nilai odds ratio di dapat 2,643 artinya responden yang berjenis kelamin lakilaki dapat menderita Arthritis Rheumatoid 2.6 kali.

\section{Hubungan Usia dengan Kejadian Arthritis} Rheumatoid pada Lansia

Tabel 4.11

Hubungan Usia dengan Kejadian Arthritis Rheumatoid pada Lansia di Wilayah Kerja Puskesmas Muara KatiTahun 2018

\begin{tabular}{cccccccc}
\hline \multirow{2}{*}{ Usia } & \multicolumn{4}{c}{ Arthritis Rheumatoid } & \multicolumn{2}{c}{ Total } & \multirow{2}{*}{$\rho$} \\
\cline { 2 - 6 } & \multicolumn{3}{c}{ Ya } & \multicolumn{2}{c}{ Tidak } & & \\
\cline { 2 - 6 } & $\mathrm{n}$ & $\%$ & $\mathrm{n}$ & $\%$ & $\mathrm{n}$ & $\%$ & \\
\hline $\begin{array}{c}\text { Usia } \\
\text { Pertengahan }\end{array}$ & 41 & 63.1 & 24 & 36.9 & 65 & 100 & \\
Usia Lanjut & 10 & 50.0 & 10 & 50.0 & 20 & 100 & 0.434 \\
\hline Jumlah & 51 & 60.0 & 34 & 40.0 & 85 & 100 & \\
\hline
\end{tabular}

Dari 65 responden yang usia pertengahan ada $41(55.3 \%)$ responden yang menderita Arthritis Rheumatoid. Dan dari 20 responden yang berusia lanjut ada $10(72.3 \%)$ menderita Arthritis Rheumatoid..

Hasil analisis Chi Square di dapat $p=$ $0,434(p<\alpha 0.05)$ dengan demikian tidak ada hubungan antara usia dengan Kejadian Arthritis Rheumatoid pada lansia.
3. Hubungan Pengetahuan dengan Kejadian Arthritis Rheumatoid

Tabel 4.12

Hubungan Pngetahuan Responden dengan Kejadian Artritis Rheumatoid pada Lansia Di Wilayah Kerja Puskesmas Muara Kati Tahun 2018

\begin{tabular}{|c|c|c|c|c|c|c|c|}
\hline \multirow{3}{*}{$\begin{array}{c}\text { Pengetah } \\
\text { uan }\end{array}$} & \multicolumn{4}{|c|}{ Arthritis Rheumatoid } & \multirow{2}{*}{\multicolumn{2}{|c|}{ Total }} & \multirow{3}{*}{$\rho$} \\
\hline & \multicolumn{2}{|c|}{$\mathrm{Ya}$} & \multicolumn{2}{|c|}{ Tidak } & & & \\
\hline & $\mathrm{n}$ & $\%$ & $\mathrm{n}$ & $\%$ & $\mathrm{n}$ & $\%$ & \\
\hline Baik & 17 & 44.7 & 21 & 55.3 & 38 & $\begin{array}{c}10 \\
0\end{array}$ & \multirow{4}{*}{0.026} \\
\hline Cukup & 11 & 64.7 & 6 & 35.3 & 17 & $\begin{array}{c}10 \\
0\end{array}$ & \\
\hline Kurang & 23 & 76.7 & 7 & 23.3 & 30 & $\begin{array}{c}10 \\
0\end{array}$ & \\
\hline Jumlah & 51 & 60.0 & 34 & 40.0 & 85 & $\begin{array}{c}10 \\
0\end{array}$ & \\
\hline
\end{tabular}

Dari responden yang pengetahuan baik ada $21(55.3 \%)$ responden yang tidak menderita Arthritis Rheumatoid, dari responden yang pengetahuan cukup ada 17 dengan 11 (64.7\%) responden menderita Arthritis Rheumatoid dan dari 30 responden yang pengetahuan kurang ada $23(76.7 \%)$ responden yang menderita Arthritis Rheumatoid.

Hasil analisis Chi Square di dapat $p=$ 0.026 ( $p<\alpha 0.05)$ dengan demikian ada hubungan antara pengetahuan responden dengan kejadian Arthritis Rheumatoid pada lansia.

\section{PEMBAHASAN}

\section{Analisa Univariat}

a. Jenis Kelamin Responden

Hasil penelitian menunjukkan bahwa bahwa sebagian besar responden yang berjenis kelamin laki-laki sebesar 54 orang (63.5\%) dan hampir sebagian dari responden yang berjenis kelamin perempuan sebesar 31 (36.5\%) orang.

Wanita lebih sering terkena Arthritis Rheumatoid lutut dan sendi, dan lelaki lebih sering terkena Arthritis Rheumatoid paha, pergelangan tangan daan leher. Secara keseluruhan dibawah 45 tahun frekuensi Arthritis Rheumatoid kurang lebih sama pada laki dan wanita tetapi diatas 50 tahun frekuensi Arthritis Rheumatoid lebih banyak pada wanita dari pada pria hal ini menunjukkan adanya peran hormonal pada patogenesis Arthritis Rheumatoid. 
Penyakit ini terdapat pada wanita 3 kali lebih sering dari pada laki-laki. Prevalensi lebih tinggi wanita dibandingkan dengan laki laki, lebih dari $75 \%$ penderita Arthritis Rheumatoid adalah wanita (Akhtyo, 2009).

\section{b. Usia Responden}

Penyakit Arthritis Rheumatoid ini tidak mengenal batas usia, dari anak-anak sampai usia lanjut. Hanya saja golongan yang lebih banyak menderita Artritis Rheumatoid ini terutama orang dewasa muda sampai pertengahan (usia kerja). Penyakit ini juga tidak mengenal jenis kelamin. Rematik atau Arthritis Rheumatoid mengakibatkan peradangan pada lapisan dalam pembungkus sendi.

Penyakit ini berlangsung tahunan, menyerang berbagai sendi biasanya simetris, jika radang ini menahun, terjadi kerusakan pada tulang rawan sendi, tulang otot ligament dalam sendi (Handriani, 2011).

\section{c. Pengetahuan Tentang Arthritis Rheumatoid}

Pengetahuan tentang Arthritis Rheumatoid masih belum tersebar luas, banyak informasi dan mitos - mitos keliru yang beredar yang menyatakan kalau Arthritis Rheumatoid ini disebabkan oleh hawa dingin, seperti mandi malam, ruang ber AC, sehingga mereka tidak dapat mengatasi atau mencegah kekambuhan penyakit ini sesuai dengan fakta sebenarnya seperti melatih pergerakan, berjemur pada pagi hari, istirahat dan tidur yang cukup (Tiksnadi, 2011).

\section{d. Kejadian Arthritis Rheumatoid pada Lansia}

Penderita Arthritis Rheumatoid di seluruh dunia telah mencapai angka 355 juta jiwa, artinya 1 dari 6 orang di dunia ini menderita Artritis Rheumatoid. Diperkirakan angka terus bertambah hingga tahun 2025 dengan indikasi lebih dari 25\% akan mengalami kelumpuhan. Munculnya penyakit ini memang pada usia lanjut.

Namun secara komulatif, jumlah penderita yang besar adalah kelompok usia lanjut dan jumlah paling kecil pada balita. WHO melaporkan bahwa $20 \%$ penduduk dunia terserang Artritis Rheumatoid dimana $5-10 \%$ adalah yang berusia diatas 60 tahun (Taja, 2011).

\section{Analisa Bivariat}

\section{a. Hubungan Jenis Kelamin Terhadap Kejadian Arthritis Rheumatoid Pada Lansia}

Hasil analisis Chi Square di dapat $p=0.059$ $(p<\alpha 0.05)$ dengan demikian tidak ada hubungan antara jenis kelamin responden dengan kejadian Arthritis Rheumatoid Pada Lansia. Dari nilai odds ratio di dapat 2,643 artinya responden yang berjenis kelamin lakilaki resiko menderita Arthritis Rheumatoid lebih besar 2.6 kali.

Dari hasil penelitian menunjukan laki-laki lebih banyak terkena Arthritis Rheumatoid dibandingkan dengan wanita. Menurut peneliti ini disebabkan oleh sistem imun dalam tubuh laki-laki yang tidak stabil, selain itu bisa dipenagruhi oleh faktor lain seperti merokok, obesitas, genetika faktor lingkungan lainnya.

Menurut teori Purwoastuti jenis kelamin adalah faktor risiko penyebab rematik, wanita lebih rawan terkena rematik dibandingkan pria, dengan faktor risiko sebesar $60 \%$. Wanita lebih sering terkena osteoarthritis lutut dan sendi dan laki-laki lebih sering terkena osteoarthritis paha, pergelangan tangan dan leher (Purwoastuti, 2009).

Penelitian ini sesuai dengan penelitian Akhtyo (2009) yang mengatakan insiden puncak dari arthritis rheumatoid terjadi pada umur dekade ke empat, dan penyakit ini terdapat pada wanita 3 kali lebih sering dari pada laki-laki. Prevalensi lebih tinggi wanita dibandingkan dengan laki laki, lebih dari $75 \%$ penderita Arthritis Rheumatoid adalah wanita. 


\section{b. Hubungan Usia dengan Kejadian Arthritis Rheumatoid pada Lansia}

Hasil analisis Chi Square di dapat $p=$ $0,434(p<\alpha 0.05)$ dengan demikian tidak ada hubungan antara usia dengan Kejadian Arthritis Rheumatoid pada lansia.

Hal ini sesuai dengan hasil penelitian Siswono (2013) dengan bertambahnya umur, penyakit ini meningkat baik wanita maupun laki laki. Puncak kejadianya pada umur 20-45 tahun dan penyakit Rheumatoid Arhtritis ini sering dijumpai pada usia di atas 60 tahun dan jarang dijumpai pada usia di bawah 40 tahun (Indonesian Rheumatoid Assosiation (IRA), 2013). Prevalensi lebih tinggi wanita dibandingkan dengan laki laki, lebih dari $75 \%$ penderita RA adalah wanita.

Penyakit Arthritis Rheumatoid ini tidak mengenal batas usia, dari anak-anak sampai usia lanjut. Hanya saja golongan yang lebih banyak menderita Artritis Rheumatoid ini terutama orang dewasa muda sampai pertengahan (usia kerja). Penyakit ini juga tidak mengenal jenis kelamin. Rematik atau Arthritis Rheumatoid mengakibatkan peradangan pada lapisan dalam pembungkus sendi. Penyakit ini berlangsung tahunan, menyerang berbagai sendi biasanya simetris, jika radang ini menahun, terjadi kerusakan pada tulang rawan sendi, tulang otot ligament dalam sendi (Handriani, 2011).

\section{c. Hubungan Pengetahuan Dengan Kejadian Arthritis Rheumatoid Pada Lansia}

Hasil analisis Chi Square di dapat $p=0.026$ $(p<\alpha 0.05)$ dengan demikian ada hubungan antara pengetahuan responden dengan kejadian Arthritis Rheumatoid pada lansia.

Hal ini sesuai dengan hasil penelitian yang dilakukan oleh Joko Purnomo (2010) bahwa ada hubungan antara tingkat pengetahuan dengan kekambuhan penyakit reumatik.

Selain itu menurut pendapat peneliti pengetahuan dengan kejadian penyakit
Arthritis Rheumatoid tidak berpengaruh besar karena di sebabkan oleh sikap dan perilaku lansia yang susah menghindari faktor-faktor yang dapat menyebabkan rematik kambuh lagi seperti tidak makan sayuran hijau dan kacang-kacangan. Seperti hasil penelitian Putri (2012) yang mengatakan pola makan yang salah menjadi salah satu pencetus terjadinya kekambuhan Arthritis Rheumatoid seperti, produk kacang-kacangan seperti susu kacang, kacang buncis, organ dalam hewan seperti; usus, hati, limpa, paru, otak, dan jantung, makanan kaleng seperti, sarden, kornet sapi, makanan yang dimasak menggunakan santan kelapa, beberapa jenis buah-buahan seperti durian, dan produk olahan melinjo, minuman seperti alkohol dan sayur seperti kangkung dan bayam (Putri, 2012).

\section{Kesimpulan Dan Saran}

\section{Kesimpulan}

1. Sebagian besar responden berjenis kelamin terhadap kejadian AthritisRheumatoid pada lansia diperoleh hasil tertinggi yaitu kategori laki-laki berjumlah 54 orang.

2. Sebagian besar Usia terhadap kejadian AthritisRheumatoid pada lansia diperoleh hasil tertinggi yaitu usia pertengahan berjumlah 47 responden.

3. Hampir sebagian dari responden pengetahuan terhadap kejadian AthritisRheumatoid pada lansia diperoleh hasil tertinggi yaitu kategori baik berjumlah 36 orang.

4. Hampir sebagian besar Kejadian AthritisRheumatoid pada lansia di wilayah kerja Puskesmas Muara Kati di peroleh hasil tertinggi yaitu responden yang menderita AthritisRheumatoid sebanyak 51

5. Tidak ada hubungan yang bermakna antara jenis kelamin terhadap kejadian AthritisRheumatoid pada lansia di 
wilayah kerja Puskesmas Muara Kati Tahun 2018.

6. Ada hubungan yang bermakna antara usia terhadap kejadian AthritisRheumatoid di wilayah kerja Puskesmas Muara Kati Tahun 2018.

7. Ada hubungan yang bermakna antara pengetahuan terhadap kejadian AthritisRheumatoid di wilayah kerja Puskesmas Muara Kati Tahun 2018.

\section{Saran}

1. Hasil penelitian ini dapat di jadikan referensi untuk penyuluhan tentang cara mendeteksi gejala dari penyakit rematik pada lansia dapat di jadikan bahan pertimbangan dalam pemberian penyuluhan kesehatan pada lansia, terutama penyuluhan tentang penyakit yang menyerang usia lanjut

\section{DAFTAR PUSTAKA}

1. Agung, 2008. Penelitian ilmiah. (http/ www.bapenas.com. Jakarta 2008) diakses tanggall6Januari 2018

2. Arikunto, Suharsimi, Prof.Dr. 2008. Prosedur Penelitian Edisi Revisi. Penerbit Rineka Cipta.Jakarta.

3. Demartoto, Argyo.2007. Pelayanan Sosial Non Panti Bagi Lansia. Penerbit UNS Press. Surakarta

4. Effendy, Nasrul.Drs.2007. Dasar-Dasar Keperawatan Kesehatan Masyarakat Edisi II. Penerbit Buku Kedokteran EGC. Jakarta

5. Hardywinoto. Dr., dkk, 2007. Panduan Gerontologi. Penerbit Gramedia Pustaka Utama. Jakarta

6. Mansjoer,A.2011. KapitaSelecta Kedokteran.Jilid 1Edisi 3Jakarta:EGC

7. Notoadmodjo,S. 2012.Metode penelitianKesehatanJakarta : PT. Rineke

8. Notoatmodjo S. 2010. Ilmu Perilaku Kesehatan Rineka Cipta : Jakarta

9. Notoatmodjo, S. Dr. Prof, 2007. Promosi Kesehatan dan Ilmu Perilaku. Penerbit Rineka Cipta.Jakarta.
10. Noer,2012.BukuAjarIlmu PenyakitDalamJilidI (EdisiKetiga).Jakarta:BalaiPenerbitFKUI

11. Nursalam, 2008. Konsep Metodologi dan Penerapan Metodologi Penelitian Ilmu Keperawatan. Penerbit Salemba Medika. Surabaya.

12. Nugroho, Wahjudi. Skp. 2007 Keperawatan Gerontik Edisi II. Penerbit Buku Kedokteran EGC. Jakarta

13. Putri, M.I, 2012. HubunganAktivitas, Jenis Kelamin Dan Pola Diet Dengan Frekuensi Kekambuhan Artritis Reumatoid di Puskesmas Nuasa Indah Bengkul, http://VI.stikesdehasen.ac.id/d owlot.pht?file $=$ memi\% zoika\%20puti,\%20S.kep.docx. diakses tanggall6Januari 2018

14. Sarwono,N. 2008.Buku AjarIlmuPenyakit Dalam Jilid I(Edisi Ketiga). Jakarta : BalaiPenerbitFKUI.

15. Sudoyo, 2007. Pedoman Pengelolaan Kesehatan Pasien Geriatri untuk Dokter dan Perawat. Jakarta: Pusat Informasi dan Penerbitan Bagian Ilmu Penyakit Dalam FKUI

16. Smeltzer, C. Suzanne, Bare, G.Brenda. 2007. BukuAjar Keperawatan MedicalBedah, BukuAjar Keperawatan MedicalBedah,vol2.Jakarta:

17. Taja, 2011. Harapan BarubagiPenderita Reumatik.MajalahIntisari. Jakarta: PT.Gramedia 